\title{
Comitê de Ética, Conflito de Interesses e Registro de Ensaios Clínicos
}

Há mais de dez anos foi instituída a Resolução 196/96 do Conselho Nacional de Saúde (CNS), sobre Diretrizes e Normas Regulamentadoras de Pesquisa Envolvendo Seres Humanos, que incorpora os quatro referenciais básicos da bioética: autonomia, não-maleficência, beneficência e justiça.

Dentro dessas Diretrizes alguns pontos devem ser ressaltados porque ocasionalmente são desconhecidos por uma parcela da população que se dedica à pesquisa em seres humanos ${ }^{1}$.

Consentimento livre e esclarecido: anuência do sujeito da pesquisa e/ou de seu representante legal, livre de vícios (simulação, fraude ou erro), dependência, subordinação ou intimidação, após explicação completa e pormenorizada sobre a natureza da pesquisa, seus objetivos, métodos, benefício previsto, potenciais riscos e incômodo que ela possa acarretar, formulada em um termo de consentimento, autorizando sua participação voluntária.

Comitês de Ética em Pesquisa (CEP): colegiados interdisciplinares e independentes, de caráter consultivo, deliberativo e educativo, criados para defender os interesses dos sujeitos da pesquisa em sua integridade e dignidade para contribuir no desenvolvimento da pesquisa dentro de padrões éticos.

As Instituições nas quais se realizem pesquisas envolvendo seres humanos deverão constituir um ou mais de um Comitê de Ética em Pesquisa, CEP, conforme suas necessidades.

$\mathrm{Na}$ impossibilidade de constituir um CEP, a instituição ou o pesquisador responsável deverá submeter o projeto à apreciação do CEP de outra instituição, preferencialmente entre os indicados pela Comissão Nacional de Ética em Pesquisa (CONEP/MS).

O CEP deverá ser constituído por colegiado com número não inferior a sete membros, com participação de profissionais da área de saúde, ciências exatas, sociais e humanas, incluindo, por exemplo, juristas, teólogos, sociólogos, filósofos, bioeticistas e pelo menos um membro da sociedade representando os usuários da instituição. O CEP deverá ser registrado junto à CONEP/MS.

Ao pesquisador cabe: a) apresentar o protocolo, devidamente instruído ao CEP, aguardando seu pronunciamento, antes de iniciar a pesquisa; b) desenvolver o projeto conforme delineado; c) apresentar dados solicitados pelo CEP a qualquer momento; d) manter em arquivo, sob sua guar$\mathrm{da}$, por cinco anos os dados da pesquisa, com todos os documentos recomendados pelo CEP; e) encaminhar os resultados para publicação, com os devidos créditos aos pesquisadores associados e ao pessoal técnico participante do projeto; justificar, perante o CEP, interrupção do projeto ou a não-publicação dos resultados.
As agências de fomento à pesquisa e o corpo editorial das revistas científicas deverão exigir documentação comprobatória de aprovação do projeto pelo CEP e/ou CONEP, quando for o caso.

Outro ponto importante em pesquisa clínica, não incluído nas diretrizes da resolução 196/96, é o conceito de conflito de interesses, que pode ser financeiro (direto ou indireto) e não financeiro. O conflito de interesses pode ser definido como um choque entre os interesses pessoais e as obrigações precípuas de um indivíduo que exerce cargo de confiança $^{2}$. O conflito de interesses surge quando um ou mais de um dos participantes do processo - sejam os pesquisadores ou o editor e/ou revisores do periódico no qual, eventualmente, o trabalho será publicado - tem ligação com instituições ou interesses que possam prejudicar a lisura da investigação ou restringir a competência ou imparcialidade da sua avaliação ${ }^{3}$.

São considerados potenciais conflitos de interesse, a relação de um autor, direta ou indiretamente através da instituição promotora da pesquisa, com empresas que eventualmente possam se beneficiar dos resultados do estudo. Os seguintes tipos de relação são considerados como potencialmente conflitantes e devem obrigatoriamente ser declarados:

Se nos últimos dois anos um dos autores recebeu honorários de consultoria, palestras, redação de textos ou quaisquer outros tipos de serviços remunerados prestados, do fabricante do produto. Recebeu auxílio do fabricante do produto (verbas de pesquisa, fornecimento de equipamentos, fármacos, mão-de-obra) relacionado com o projeto em análise ou outro projeto que envolva o mesmo produto. Recebeu auxílio do fabricante do produto para participação em congressos. Deteve ações do fabricante. Houve envolvimento do fabricante do produto na coleta, análise, interpretação ou redação dos dados. É empregado de empresa que possa se beneficiar direta ou indiretamente com os resultados do estudo ${ }^{4}$.

De modo geral as pessoas tendem a identificar conflito de interesses apenas como situações que envolvem aspectos econômicos. Outros importantes aspectos devem ser lembrados como: interesses pessoais, científicos, assistenciais, educacionais, religiosos e sociais.

Os editores podem ou não publicar as informações sobre conflito de interesses, encaminhadas pelos pesquisadores, de acordo com a avaliação de que as relações existentes e relatadas possam efetivamente influenciar nos conceitos emitidos.

Como último item de interesse dos pesquisadores é preciso mencionar o Registro de Ensaios Clínicos. Em 2004, o International Committee of Medical Journal Editors (ICMJE), grupo que representa 11 revistas médicas de prestígio, 
emitiu declaração que suas revistas passariam a solicitar registro de ensaio clínico, como condição para que o trabaIho fosse analisado com vistas à publicação ${ }^{5}$. A definição aceita para ensaio clínico foi a de projeto com recrutamento prospectivo de sujeitos de pesquisa para estudar a relação de causa e efeito entre uma intervenção e um desfecho clínico. Em julho de 2005, a World Association of Medical Editors passou a apoiar a política de registros de ensaios clínicos. Em 2006, a Organização Mundial de Saúde (OMS) anunciou os novos padrões para registro de toda pesquisa médica em seres humanos, estimulando que os registros fossem realizados.

Em 2007, o ICMJE adotou a definição de ensaio clínico da OMS que inclui os ensaios preliminares (fase I): qualquer estudo que recrute prospectivamente sujeitos de pesquisa para serem submetidos a intervenções relacionadas com a saúde (fármacos, procedimentos cirúrgicos, aparelhos, terapias comportamentais, dietas, modificações nos cuidados de saúde), com finalidade de avaliar os efeitos sobre os desfechos clínicos (qualquer variável biomédica ou relacionada com a saúde, inclusive medidas farmacocinéticas e efeitos adversos).

Em 2007, a BIREME recomendou que todos os periódicos indexados nas bases de dados LILACS e SciELO incluam orientação para o registro dos ensaios controlados aleatórios e ensaios clínicos e que o número de identificação seja disponibilizado após o resumo.

Para realizar o registro é necessário seguir os passos propostos pela OMS, que desenvolveu uma plataforma gerenciadora dos endereços que realizam os registros (www.who.int/ictrp/en/) ${ }^{6}$. Há três grupos de portais para realizar os registros.

Os registradores primários, que atendem a todas as normas da plataforma da OMS e do ICMJE, são:

- Australian New Zealand Clinical Trials Registry

- Chinese Clinical Trial Register (ChiCTR)

- Clinical Trials Registry - Índia (CTRI)

- ISRCTN.org

Os dados encaminhados pelo ClinicalTrials.gov são incluídos no portal de busca da OMS, embora ele não seja considerado um registrador primário.

Os outros dois grupos são os registradores associados e os potenciais, que estão se adaptando às normas ou solicitando sua inclusão, respectivamente.

No último grupo há o Latin American Clinical Trials Register (LatinRec) que deverá, quando aprovado, ser o canal preferencial dos pesquisadores da América Latina e do Caribe.

Todas essas etapas que aparentemente burocratizaram o impulso primário do pesquisador - a pergunta sem resposta - têm como finalidade precípua garantir a segurança da pesquisa clínica, assegurar aos sujeitos das pesquisas que a informação obtida como resultado de seu altruísmo será de domínio público e subsidiar a medicina baseada em evidências.
Unitermos: BIOÉTICA; ÉTICA MÉDICA.

Dra. Judymara Lauzi Gozzani, TSA

Editor-Chefe da Revista Brasileira de Anestesiologia

\section{Ethics Committee, Conflict of Interest, and Registry of Clinical Assays}

The resolution 196/96 of the National Health Board (CNS Conselho Nacional de Saúde) on Directives and Principles of Research on Humans) was instituted more than ten years ago, and incorporated four basic bioethical principles: autonomy, nonmaleficence, beneficence, and justice.

Some of those directives should be emphasized because, occasionally, they might be unknown by those dedicated to research in humans ${ }^{1}$.

Informed Consent: indicates that the individual and/or his/ her legal guardian agrees to participate in the study, without vice (simulation, fraud, or mistake), addiction, subordination, or intimidation, after complete and detailed explanation of the nature of the study, its objectives, methods, foreseen benefits, potential risks, and discomfort that it may cause, formulated in the terms of a consent agreeing to his/her voluntary enrollment.

Ethics Committees on Research (ECR) (Institutional Review Board - IRB) interdisciplinary and independent council with an advisory, deliberative, and educational role, created to defend the interests of individuals participating in studies, their integrity and dignity, therefore guaranteeing that the studies remain within ethical standards.

Institutions involved in research in humans should institute one or more than one Ethics Committees on Research ECR, according to their needs.

If an ECR cannot be instituted, the institution or the researcher in charge should submit the study to the appreciation of the ECR of another institution, preferably one of those indicated by the National Committee of Ethics on Research (Comissão Nacional de Ética em Pesquisa - CONEP/MS). The ECR should have at least seven members, with health care professionals, and representatives of exact, social, and human sciences, including, for example, lawyers, theologians, sociologists, philosophers, bioethicists, and at least one member of society, representing those who use the institution. The ECR should be registered in the CONEP/MS. The researcher should: a) present a study protocol to the ECR and await its ruling before starting the study; b) implement the study according to the protocol; c) present the data requested by the ECR at any time; d) keep the study data, along with all the documents recommended by the ECR, for 5 years; and e) submit the data for publication, giving credit to associate researchers and technical personnel; justify to the ECR the interruption of the study or nonpublication of the results. 
Research promotion agencies and the editorial board of scientific journals should request the ECR and/or CONEP documents approving the project.

Another important aspect of clinical studies, which is not included in the directives of the 196/96 resolution, is the concept of conflict of interest, which can be financial (direct or indirect) and non-financial. Conflict of interest can be defined as a clash between personal interests and the obligations of an individual in a position of trust ${ }^{2}$. Conflict of interest arises when one or more than one of those involved with the project - may it be researchers, or editor and/or reviewer of the journal in which the work will be published - is connected to institutions or interests that might hinder the fairness of the study or restrict the competence or impartiality of his/her evaluation ${ }^{3}$.

The direct or indirect relationship of the author, through the institution promoting the study, with companies that might eventually benefit from the results of the study is considered as a potential conflict of interest. The following types of relationships are considered as potentially conflicting and should be stated:

If in the prior two years one of the authors received consulting fees, was paid for conferences, writing texts, or provided any other paid services to the manufacturer of the product. If the researcher received any aid from the manufacturer of the product (research funds, equipment, drugs, labor workers) related to the current study or other study involving the same product. If the researcher received financial aid from the manufacturer of the product to participate in meetings. If the researcher owned stocks of the manufacturer. The manufacturer was involved in gathering, analysis, interpretation, or writing of the data. If the researcher is an employee of a company that might benefit, directly or indirectly, from the results of the study ${ }^{4}$.

In general, there is a tendency to identify conflict of interest only as situations involving financial aspects. Other important aspects should be remembered, such as: personal, scientific, supportive, educational, religious, and social interests.

Editors might publish or not the information on conflict of interest submitted by the researchers according to their evaluation of whether the existing relationship might effectively influence the final result.

Finally, the Registry of Clinical Trials should also be mentioned. In 2004, the International Committee of Medical Journal Editors (ICMJE), a group that represents 11 renowned medical journals, stated that they would request the registry of clinical trials as a prerequisite for evaluating the work for publication ${ }^{5}$. The accepted definition of a clinical trial was that of a project with prospective recruiting of subjects to study the cause-effect relationship between an intervention and the clinical outcome. In July 2005, the World Association of Medical Editors announced its support to the policy of requiring the registry of clinical trials. In 2006, the
World Health Organization (WHO) announced the new standards for registry of clinical studies in humans, encouraging such registries.

In 2007, the ICMJE adopted the definition of clinical trials of the WHO, which includes preliminary trials (phase I): any study with prospective recruiting of subjects to undergo any health-related intervention (drugs, surgical procedures, equipment, behavioral therapies, changes in health care) to evaluate the effects on clinical outcomes (any biomedical or health-related parameter, including pharmacokinetic measurements and adverse reactions).

In 2007, BIREME recommended that all journals in the LILACS and SciELO database included the orientation for registry of randomized trials and clinical studies and that the identification number should be present after the summary. To register a study, it is necessary to follow the steps proposed by the WHO, which developed a platform for the management of the addresses responsible for such registries (www.who.int/ictrp/en) ${ }^{6}$. There are three portal groups to implement the registries.

The primary register that fulfill the standards of the WHO platform and of the ICMJE include:

- Australian New Zealand Clinical Trials Registry

- Chinese Clinical Trial Register (ChiCTR)

- Clinical Trials Registry - India (CTRI)

- ISRCTN.org

The data submitted by the ClinicalTrials.gov are included in the WHO search site, although it is not considered a primary register.

Another two groups are associated and potential registers, which are adapting themselves to the standards or requesting their inclusion, respectively.

The Latin American Clinical Trials Register (LatinRec) is included in the last group, and should be the preferential channel of researchers in Latin America and Caribe once it is approved.

All those steps, which apparently imprint a bureaucratic form to the primary impulse of the researcher - to ask a question -, are aimed at guaranteeing the safety of clinical trials, ensure to the study subjects that the information obtained from their altruism will be of public domain, and subsidize evidence-based medicine.

Key Words: BIOETHICS; MEDICAL ETHICS

Dr. Judymara Lauzi Gozzani, TSA

Editor-in-Chief of the Brazilian Anesthesiology Journal

\section{REFERÊNCIAS - REFERENCES}

01. Conselho Nacional de Saúde - Resolução 196/96 Diretrizes e Normas Regulamentadoras de Pesquisas Envolvendo Seres Humanos. Disponível em: <http://www.ufrgs.br/bioetica/ res19696.htm>. Acesso em: 02 jan. 2008.

02. Houaiss A, Villar MS - Dicionário Houaiss da Língua Portuguesa. Rio de Janeiro, Objetiva, 2001. 


\section{EDITORIAL}

03. Alves EMO, Tubino $P$ - Conflito de interesses em pesquisa clínica. Acta Cir Bras, 2007;22: 412-415.

04. Normas de Vancouver - Requisitos uniformes para originais submetidos a revistas biomédicas. Disponível em: <http:// www.abem-educmed.org.br/rbem/normasdevancouver.htm>. Acesso em: 02 jan. 2008.
05. Guimarães CA — Registro de ensaios clínicos. Rev Col Bras Cir 2007; 34:201- 204.

06. World Health Organization - International Clinical Trials Registry Platform (ICTRP). Disponível em: <http://www.who.int/ ictrp/en/>. Acesso em: 02 jan. 2008. 